\title{
Floral structure and pollen morphology of two zinc violets (Viola lutea ssp. calaminaria and $V$. lutea ssp. westfalica) indicate their taxonomic affinity to Viola lutea
}

\author{
Elżbieta Kuta • Jerzy Bohdanowicz • \\ Aneta Słomka $\cdot$ Maria Pilarska $\cdot$ Hermann Bothe
}

Received: 20 May 2011/Accepted: 24 October 2011/Published online: 26 November 2011

(C) The Author(s) 2011. This article is published with open access at Springerlink.com

\begin{abstract}
Two zinc violets, the yellow form of the Aachen-Liège area and the blue morph of Blankenrode in western Westphalia, have very restricted occurrence on heavy metal waste heaps. Their taxonomic affinities have not been finally resolved. The flower micromorphological analysis presented here indicates that both zinc violets are closely related to the alpine Viola lutea, in line with our earlier published molecular data, but not with the conclusions of other authors. The zinc violets are classed at the rank of subspecies as V. lutea: ssp. calaminaria for the yellow zinc violet and ssp. westfalica for its blue counterpart. Although the violets examined (V. lutea, V. lutea ssp. calaminaria, $V$. lutea ssp. westfalica) are closely related, there is no evidence that $V$. lutea ssp. westfalica is a descendent of $V$. tricolor. Here we provide the most detailed information on generative organ structure in the four violets studied.
\end{abstract}

E. Kuta $\cdot$ A. Słomka $(\bowtie)$

Institute of Botany, Jagiellonian University, Grodzka 52,

31-044 Cracow, Poland

e-mail: a.slomka@iphils.uj.edu.pl

J. Bohdanowicz

Department of Plant Cytology and Embryology,

University of Gdańsk, Kładki 24, 80-822 Gdańsk, Poland

M. Pilarska

Department of Plant Biotechnology, Jagiellonian University, Gronostajowa 7, 30-387 Cracow, Poland

H. Bothe

Botanical Institute, University of Cologne, Zülpicherstr. 47b,

50-923 Cologne, Germany
Keywords Metallophytes - Viola $\cdot$ Violet reproductive organs · Zinc violets · Central European endemites · SEM analysis

\section{Introduction}

The occurrence of two endemic zinc violets of Central Europe is restricted. The yellow zinc violet grows on heavy metal heaps (mainly Zn-contaminated soils) between Aachen, Germany and Liège, Belgium, with a spot distribution (Bizoux et al. 2004, 2008; Lucassen et al. 2010). The blue zinc violet is found only at a medieval $\mathrm{Cu}-\mathrm{Pb}$ mine and its surrounding meadow covering an area of $1 \mathrm{~km} \times 0.5 \mathrm{~km}$, with waste overflow from a ditch, at Blankenrode close to Paderborn, western Westphalia, Germany. These two violets are the most endangered plants in Central Europe and are assigned top priority for plant protection.

The two zinc violets belong to sect. Melanium Ging. of the genus Viola L., but otherwise their taxonomic affinity and phylogeny are not clear. Nauenburg (1986) classified the yellow form as $V$. lutea subspecies calaminaria [Viola lutea ssp. calaminaria (Ging. in DC.) comb. et stat. nov], which stresses relatedness to the alpine Viola lutea Huds. in line with earlier suggestions (Ernst 1974). On the other hand, based on flower and leaf morphology and on distribution, Nauenburg (1986) classed the blue zinc violet as a species in its own right (Viola guestphalica Nauenburg, spec. nova), and this is accepted in the current standard German flora (Schmeil and Fitschen 2010). Based on chromosome number, Nauenburg (1986) suggested the blue zinc violet to be an autoploid $(2 n=52)$ of Viola tricolor L. $(2 n=26)$; for the yellow zinc violet it is $2 n=48$ (Kakes and Everards 1976) or $2 n=52$ (Gadella 1963). Several chromosome numbers have been reported 
for $V$. lutea: $2 n=48,50$ or 52 (Marhold et al. 2007; http://www.floranordica.org) and chromosome variability in V. tricolor (Słomka et al. 2011d).

Molecular analyses yielded different information for the blue zinc violet. Using DNA sequencing of the ITS1-5.8S rDNA-ITS2, Hildebrandt et al. (2006) found the two zinc violets to be closely related and to have strong affinity to $V$. lutea but not to $V$. tricolor. They suggested that both zinc violets are at best subspecies or even forms of $V$. lutea and therefore proposed the names $V$. lutea ssp. calaminaria and $V$. lutea ssp. westfalica, in accord with earlier suggestions on the taxonomic status of the yellow zinc violet (Runge 1972 quoted in Nauenburg 1986).

Since the published morphological and chromosomal measures and the molecular data do not match, a more detailed characterization of both zinc violets and their potential relative(s) was needed, particularly at the micromorphological level.

Flower structures are essential for diagnoses within the genus Viola. The shape of the pistil, especially of the style and stigma, and whether endowed with papillae and hairs or not, proved crucial in very early classifications of the genus Viola (Ging 1823 and Becker 1925 quoted by Clausen 1927, 1929). Violets of sect. Melanium have a characteristic stigma morphology. The stigma is cup-shaped, with an opening (hole) on the top and a typical lip below the hole. On its outer surface the stigma is covered with papillae and hairs differing in size, abundance and distribution depending on the species (Kraemer 1899; Church 1908; Kroon 1972; Beattie 1974). The structure of violet flowers is an evolutionary trait adapted to pollinators and also to many ecological conditions (Beattie 1974). Species of sect. Melanium develop exclusively chasmogamous flowers with no cleistogamy, which is a characteristic feature for sect. Viola. In addition, pollen heteromorphism, another diagnostic character for species within sect. Melanium (Nadot et al. 2000), is independent of polyploidy in sect. Melanium, unlike in sect. Viola (Nadot et al. 2000), and it also has a selective advantage (Dajoz 1999).

Having these diagnostic features in mind, here we aimed to characterize the reproductive organs of these violets in detail using scanning electron microscopy (SEM) to shed light on the relatedness of zinc violets and to solve the controversial problem of their descent from either $V$. lutea or V. tricolor.

\section{Materials and methods}

Plant material

Flowers of $V$. lutea ssp. westfalica were collected from plants growing on the lead waste heap at D-Blankenrode $\left(51^{\circ} 32^{\prime} 13^{\prime \prime} \mathrm{N}, 8^{\circ} 54^{\prime} 35^{\prime \prime} \mathrm{E}\right)$ and in a private garden in D-Erftstadt-Bliesheim $\left(50^{\circ} 46^{\prime} 49^{\prime \prime} \mathrm{N}, 6^{\circ} 49^{\prime} 65^{\prime \prime} \mathrm{E}\right)$. Flowers of $V$. lutea ssp. calaminaria were collected from a meadow outside a nature protection area close to D-Breinigerberg village, Stolberg/Aachen $\left(50^{\circ} 44^{\prime} 58^{\prime \prime} \mathrm{N}, 6^{\circ} 14^{\prime} 19^{\prime \prime}\right.$ E). Flowers of $V$. lutea (blue and yellow morphs) were collected from the Vosges Mountains at F-Hohneck $\left(48^{\circ} 01^{\prime} 73^{\prime \prime} \mathrm{N}\right.$, $7^{\circ} 00^{\prime} 34^{\prime \prime} \mathrm{E}$ ), flowers of $V$. lutea ssp. sudetica from the Sudeten Mountains at PL-Śnieżnik $\left(50^{\circ} 12^{\prime} 00^{\prime \prime} \mathrm{N}, 16^{\circ} 49^{\prime} 60^{\prime \prime} \mathrm{E}\right)$ under a permit to collect material outside the Śnieżnik Kłodzki Reserve and flowers of $V$. tricolor from the calamine heaps at PL-Bukowno near Olkusz $\left(50^{\circ} 15^{\prime} 54^{\prime \prime} \mathrm{N}\right.$, $19^{\circ} 26^{\prime} 41^{\prime \prime}$ E). Only a few flowers (5-8) were harvested from several plants (1-2 from each plant) of the two rare zinc violets at their natural sites, so as not to damage these endangered species, and 10-15 flowers each were taken from $V$. lutea ssp. sudetica and $V$. tricolor. Fresh flowers were examined under a stereomicroscope.
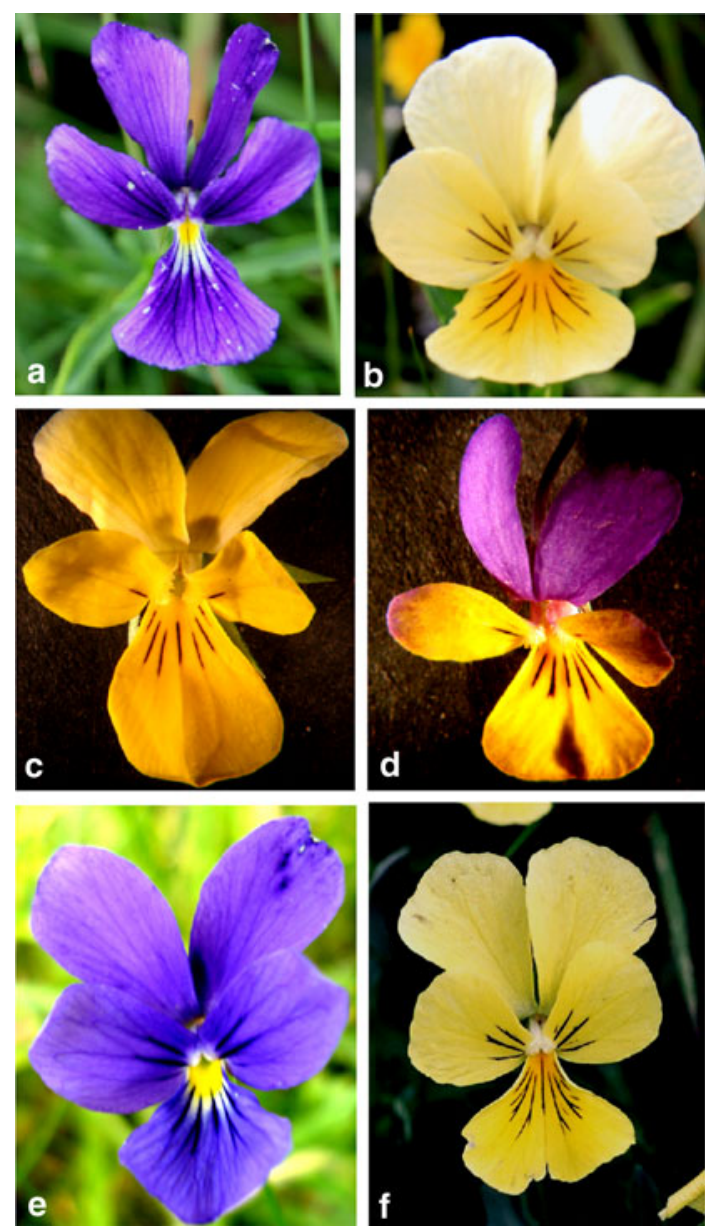

Fig. 1 Flower color, petal shape and veins or "pencil lines" (nectar guides) in: Viola lutea from Vosges Mountains; blue (a), yellow (b), morphs, $V$. tricolor $(\mathbf{c}, \mathbf{d}), V$. lutea ssp. westfalica from Blankenrode (e), V. lutea ssp. calaminaria (f) 

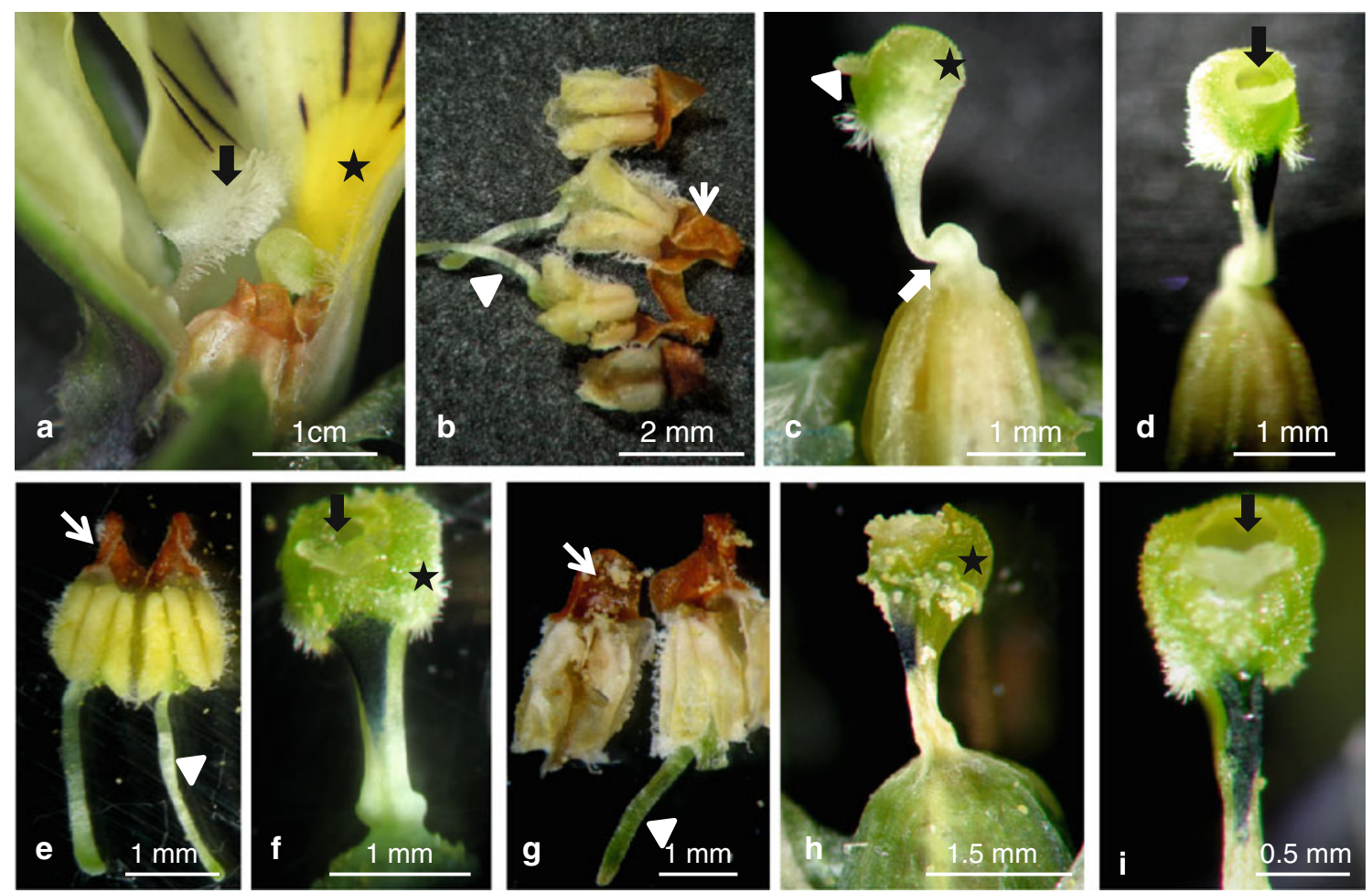

Fig. 2 Gynoecium and androecium of different violets: a-d Viola lutea ssp. sudetica. e, f V. tricolor. $\mathbf{g}, \mathbf{h} V$. lutea ssp. calaminaria. i V. lutea ssp. westfalica from Blankenrode. Visible hairs on lateral petal (arrow on a), dark veins on lateral and anterior petals and darker yellow basal patch on anterior petal (asterisk on a), filamentless stamens, two with nectariferous appendages (arrowheads on $\mathbf{b}, \mathbf{e}, \mathbf{g}$ ) and connective

\section{Scanning electron microscopy (SEM)}

Flowers for study by SEM were fixed in $100 \mathrm{ml}$ formalinacetic acid-alcohol (FAA) (5 ml 40\% formaldehyde, $5 \mathrm{ml}$ glacial acetic acid, $90 \mathrm{ml} 70 \%$ ethanol) or $4 \%$ glutaraldehyde in $0.1 \mathrm{M}$ Na-cacodylate buffer, dehydrated in an ethanol series and critical-point dried using liquid $\mathrm{CO}_{2}$ and a K850 critical point dryer (EMITECH, Ashford, England). Pollen grains (dry or briefly rehydrated in a nearly watersaturated atmosphere) were prepared according to Halbritter (1998). Dried flower parts were mounted on, and dried pollen grains were dusted onto, stubs with SPI carbonconductive double-sided adhesive discs, gold-coated (SPIMODULE $^{\mathrm{TM}}$ Sputter Coater, Structure Probe, Inc., Chester, PA, USA) and examined in a Philips XL 30 SEM.

\section{Results}

Morphological traits of the corolla by visual inspection

All examined taxa have exclusively chasmogamous, bi-sexual, zygomorphic flowers with the perianth differentiated into appendages (arrows on $\mathbf{b}, \mathbf{e}, \mathbf{g}$ ). Thin and knee-shaped lower part of style (arrow on c); head-like upper part (black asterisks on c, f, h), entrance to stigmatic chamber (hollow) (black arrows on d, f, i), labellum (epidermal outgrowth) under the hollow (arrowhead on c), dark spot on style below stigma (visible on $\mathbf{d}, \mathbf{f}, \mathbf{h}, \mathbf{i}$ )

five distinct sepals and five petals differing in color, shape and size. The two obovate posterior (upper) petals are erect in most specimens and do not overlap in V. lutea (Fig. 1a, b) or in either zinc violet (Fig. 1e, f), but are slightly recurved and partly overlapping in $V$. tricolor (Fig. 1c, d). The two narrowly obovate lateral petals are directed upwards in all taxa (Fig. 1). The obdeltate anterior petal producing the spur (spurred petal) is much larger than other petals (Fig. 1) and acts as a landing platform for pollinators. In all species the base of the lateral and anterior petals (at the throat of the flower) possesses hairs that close the entrance to the cavity containing the pollen. These petals also show veins or "pencil lines," which guide pollinators to nectar and pollen. These lines are dark and clearly visible on the petals. The lateral lines but not the middle one are branched in V. lutea (Fig. 1a, b) and in both zinc violets (Fig. 1e, f), but show only one type of line in V. tricolor (Fig. 1c, d).

Petal color conspicuously varies in $V$. lutea from the Vosges Mountains where the specimens develop flowers with blue, yellow (Fig. 1a, b) or several intermediate colors. V. tricolor develops numerous morphs, varying from unicolored yellow (Fig. 1c) flowers to bi-colored specimens, which are light blue and almost white with a 
Fig. 3 Viola lutea from Vosges Mountains-flower parts (SEM): a, b style and stigma, visible hairs (asterisks) and papillae (arrow). c-h Anterior petal: c part of petal with spur (asterisk) and hairs (arrow, magnified in $\mathbf{f}$ ). $\mathbf{d}$ Part of petal with hairs in basal part (magnified in e). g Adaxial epidermis cells. h Abaxial epidermis cells. $\mathbf{i}-\mathbf{k}$ Lateral petal: hairs in basal part (i), adaxial epidermis cells (j) and abaxial epidermis cells $(\mathbf{k})$
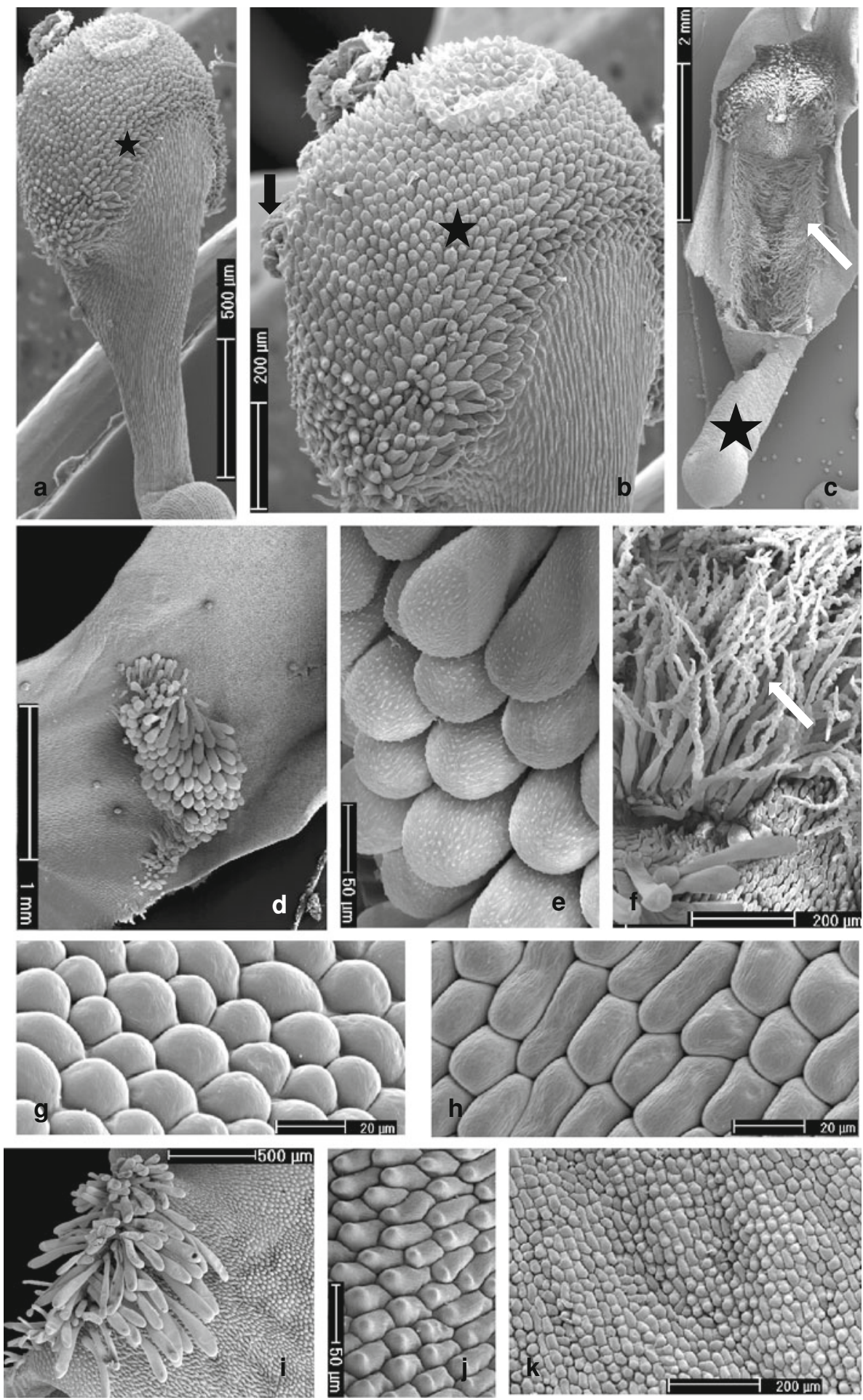

yellow basal patch, or yellow-violet (Fig. 1d) and yellowwhitish, or finally tricolored. Most $V$. lutea ssp. westfalica and $V$. lutea ssp. calaminaria have uniformly colored flowers, dark blue or light yellow with a darker yellow basal patch, respectively (Fig. 1e, f). Flowers of $V$. lutea ssp. sudetica from the Sudeten Mountains are completely yellow in most specimens. Thus, flowers of the zinc violets and $V$. lutea are not as variable as $V$. tricolor flowers.

Petal micromorphology observed by SEM

The petal abaxial and adaxial epidermis differs in cell shape and size, and has the same structure in all analyzed 
Fig. 4 Viola lutea ssp. sudetica-flower parts (SEM): a-c style and stigma, visible hollow, hairs (asterisks) and papillae on stigma lip (arrowheads). d Filamentless stamen with anthers (asterisk) and nectary (arrowhead); visible anther appendix (arrow) and lateral anther hairs (white arrow), inset: nectary with papillae in basal part (arrow) and hairs in apical part (in parentheses). e Stomata in nectary epidermis (arrows). $\mathbf{f}-\mathbf{h}$ Anterior petal: part of spur with hairs (f, magnified in $\mathbf{g}$ ). $\mathbf{h}$ Basal part of petal with hairs (arrowhead) and papillae (asterisk). i-n Lateral petal: hairs in basal part (i), adaxial epidermis cells $(\mathbf{k}, \mathbf{l})$, abaxial epidermis cells $(\mathbf{m}, \mathbf{n})$. o-s Anterior petal: adaxial epidermis cells $(\mathbf{o}, \mathbf{p})$ and abaxial epidermis $(\mathbf{r}, \mathbf{s})$
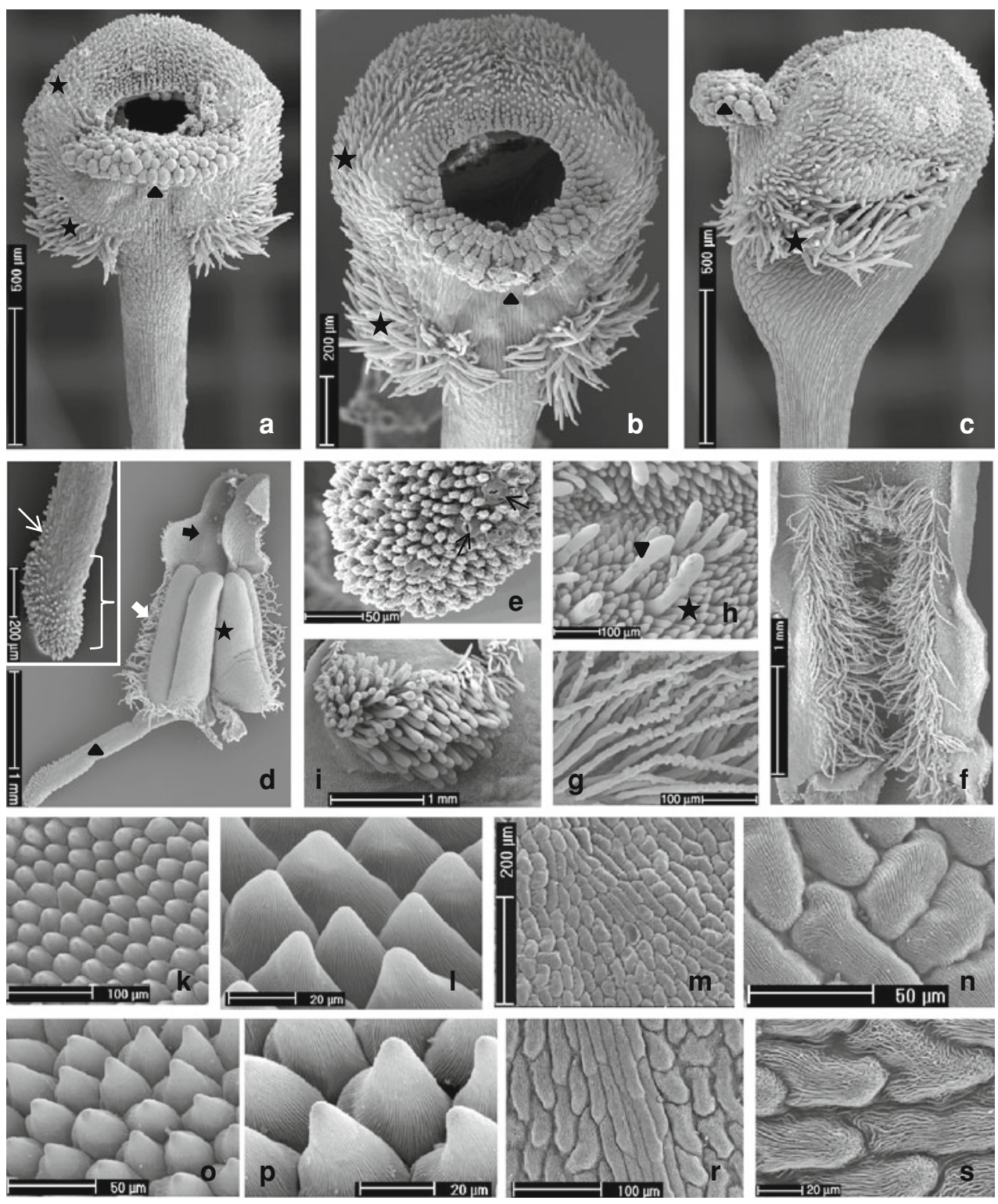

taxa. Cells of the adaxial epidermis of all petal types form conical papillae covered by striate cuticular ornamentation (Figs. 3g, j; 4k, 1, o, p; 5l-n, r, s; 6j; 7p). Cells of the abaxial epidermis are not papillate, vary in shape, and are covered by a longitudinally ridged cuticle (Figs. 3h, j, k; $4 \mathrm{~m}, \mathrm{n}, \mathrm{r}, \mathrm{s} ; 5 \mathrm{o}, \mathrm{p}, \mathrm{t}, \mathrm{u} ; 7 \mathrm{o}$ ). Thus, the epidermis does not provide data to differentiate $V$. lutea from $V$. tricolor.

Hairs on the anterior (spurred) petal differ in length between the top and bottom. They are relatively short at the base of the petal (Figs. 3d, e; 4h), and rather long with a characteristic shape at the entrance to the spur and inside the spur (Figs. 3f; 4f, g; 5h-j; 7h). They resemble sausages, with regular thickenings followed by constrictions. Hairs at the base of lateral petals are uniform (not thickened) in shape (Figs. 3i; 4i; 5k; 6i; 7n).
Pistil (especially style and stigma) micromorphology

The gynoecium of all examined taxa consists of a single pistil with a single style ending with a stigma and a superior ovary (Fig. 2a). Pistil features are generally similar in zinc violets, V. lutea and V. tricolor. The lower part of the style (border between ovary and style) is thin and knee-shaped (Figs. 2c; 3a; 5a-c; 7a, b), whereas the upper part (stigma) is head-like (Figs. 2c, f, h; 3a, b; $4 \mathrm{a}-\mathrm{c}$; 5a-d; 6a, b; 7a-d); the upper part is bordered by longer hairs, with shorter ones on the head (Figs. 3a, b; $4 \mathrm{a}-\mathrm{c} ; 5 \mathrm{a}-\mathrm{d} ; 6 \mathrm{a}-\mathrm{e} ; 7 \mathrm{a}-\mathrm{g})$. Those features are the same in all species. There is a characteristic hollow, the entrance to the stigmatic chamber, at the top of the stigma. An epidermal outgrowth forms a papillate labellum (lip) 

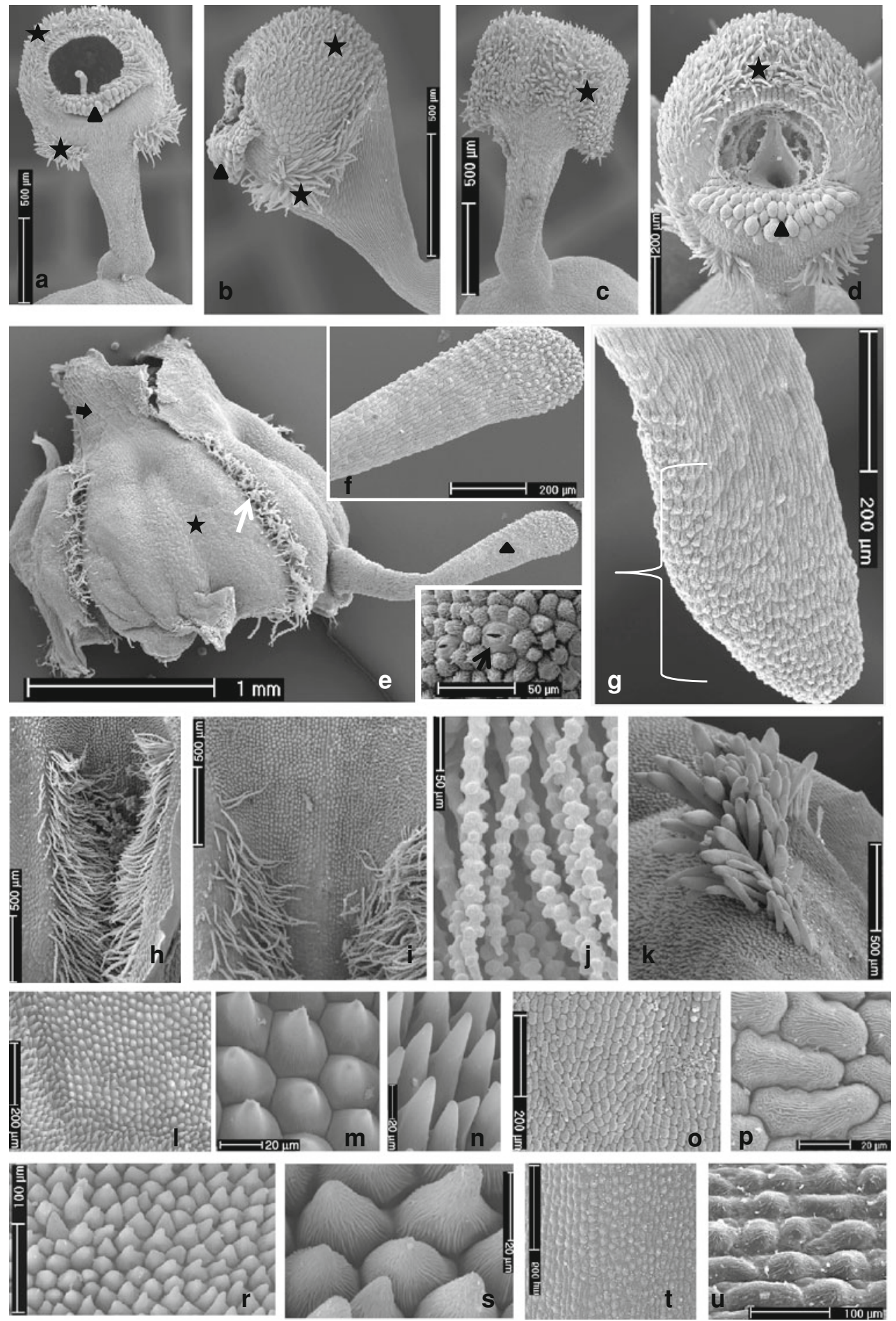

Fig. 5 Viola tricolor-flower parts (SEM): a-d style and stigma, visible hollow, hairs (asterisks) and papillae on stigma lip (arrowheads). e-g Filamentless stamens with anthers (asterisk) and nectary (arrowhead); visible anther appendix (arrow) and lateral anther hairs (white arrow). f, $\mathbf{g}$ Nectary with hairs in apical part (parenthesis), inset:

under the hollow (Figs. 2d, f, i; 4a-c; 5a, b, d; 6a-c; $7 \mathrm{a}-\mathrm{d})$. Styles of each taxon have a dark green triangular spot on their anterior part, guiding pollinators to the stomata in epidermis (arrow). $\mathbf{h}-\mathbf{j}$ Anterior petal: part of petal spur with hairs (magnified in $\mathbf{j}$ ). $\mathbf{k}-\mathbf{p}$ Lateral petal: hairs in basal part (k), adaxial epidermis cells (l-n), abaxial epidermis cells $(\mathbf{o}, \mathbf{p})$. $\mathbf{r}-\mathbf{u}$ Anterior petal: adaxial epidermis cells $(\mathbf{r}, \mathbf{s})$ and abaxial epidermis $(\mathbf{t}, \mathbf{u})$

nectar deposited in the spur (Fig. 2d, f, h, i). There are no conspicuous differences between the examined species. 

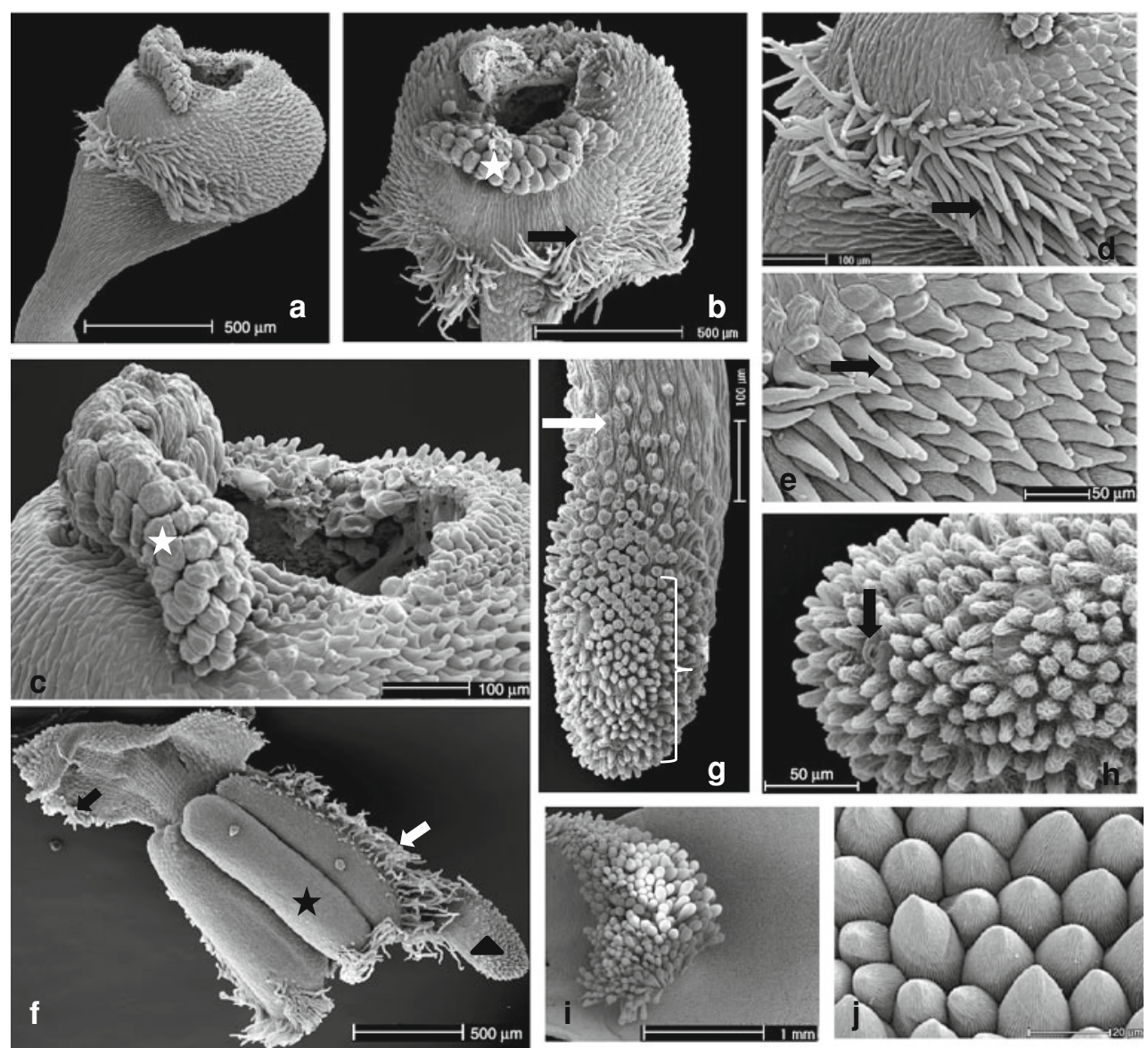

Fig. 6 Viola lutea ssp. calaminaria-flower parts (SEM): a-e stigma with hollow, papillae (asterisk, magnified in c) and hairs (arrows, magnified in d, e). f Filamentless stamens with anthers (asterisk) and nectary (arrowhead), visible hairy anther appendix (arrow) and

Stamen micromorphology

The androecium of the examined Viola taxa consists of five filamentless stamens (stamina), each with two anthers sticking closely together by their lateral hairs. The anthers surround the style and ovary of the pistil (Figs. 4d; 5e; 6f; $7 \mathrm{a}, \mathrm{k}, \mathrm{l})$. Each stamen has yellowish to orange connective appendages bordered by hairs (Figs. 4d; 5e; 6f; 7k, m). The two lowermost anthers develop nectariferous appendages (nectaries), which project back into the spur of the anterior petal (Figs. 4d; 5e; 6f; 7h, i). The size of nectaries and the type and distribution of hairs and papillae differ depending on the taxon. In $V$. lutea and the two zinc violets, the epidermis of nectariferous appendages forms densely distributed papillae in the basal part and short hairs in the apical part (Figs. 4d, e; 6g, h; 7i). In $V$. tricolor, short hairs are formed in the apical part, and no papillae can be seen in the basal part (Fig. 5e-g). There are stomata in the epidermis of nectaries of all species (Figs. 4e; 5e-inset; 7j). lateral anther hairs (white arrow). $\mathbf{g}, \mathbf{h}$ Nectary with papillae in basal part (arrow) and hairs in apical part (parenthesis), visible stomata in epidermis (arrow, magnified in h). $\mathbf{i}$ Part of lateral petal with hairs in basal part, and adaxial epidermis cells (j)

The pollen of the zinc violets, $V$. lutea and $V$. tricolor, is heteromorphic. Several pollen morphs develop, differing in size, shape and number of apertures within one anther or even one pollen sac of a particular violet. In all taxa, 4-aperturate (colporate) pollen grains are most abundant, and 3- and 5-aperturate ones less abundant (Figs. 8; 9). As previously found by histochemical staining and analysis, the two zinc violets, $V$. tricolor from waste heaps and alpine $V$. lutea, possess more than $80 \% 4$-aperturate pollen, and 5- and 6-aperturate pollen at low frequency (Hildebrandt et al. 2006; Słomka et al. 2010). Dwarf, degenerated pollen appeared sporadically in $V$. lutea ssp. calaminaria (Fig. 9a, b) and were quite frequent in V. lutea ssp. westfalica (Fig. 9e, f). No degenerated pollen was found in $V$. lutea from the Vosges and Sudeten Mountains or in $V$. tricolor. They all had almost exclusively 4-aperturate (colporate) pollen grains. Thus, pollen morphology is not diagnostic for differentiation of these species. 

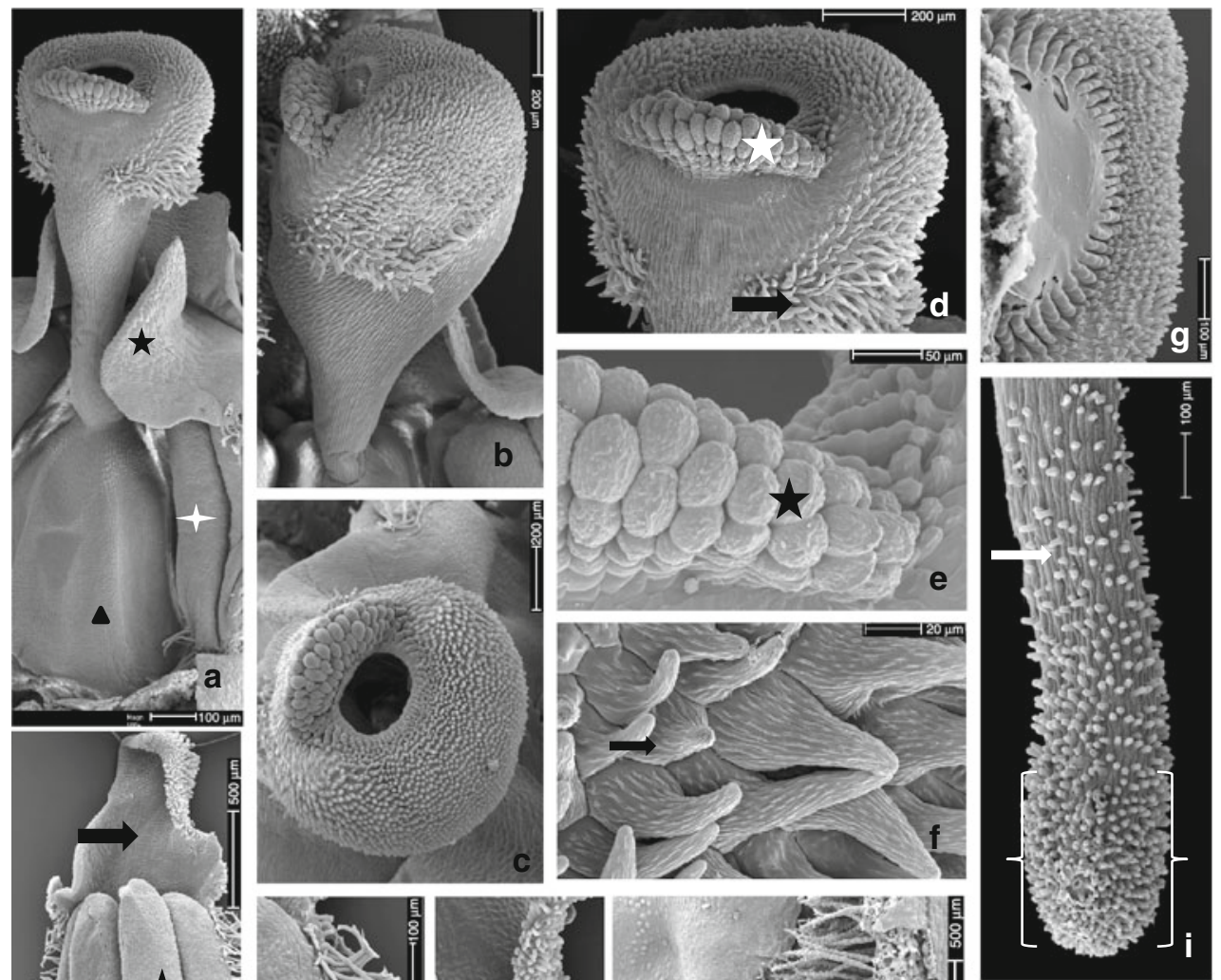

$\triangle$
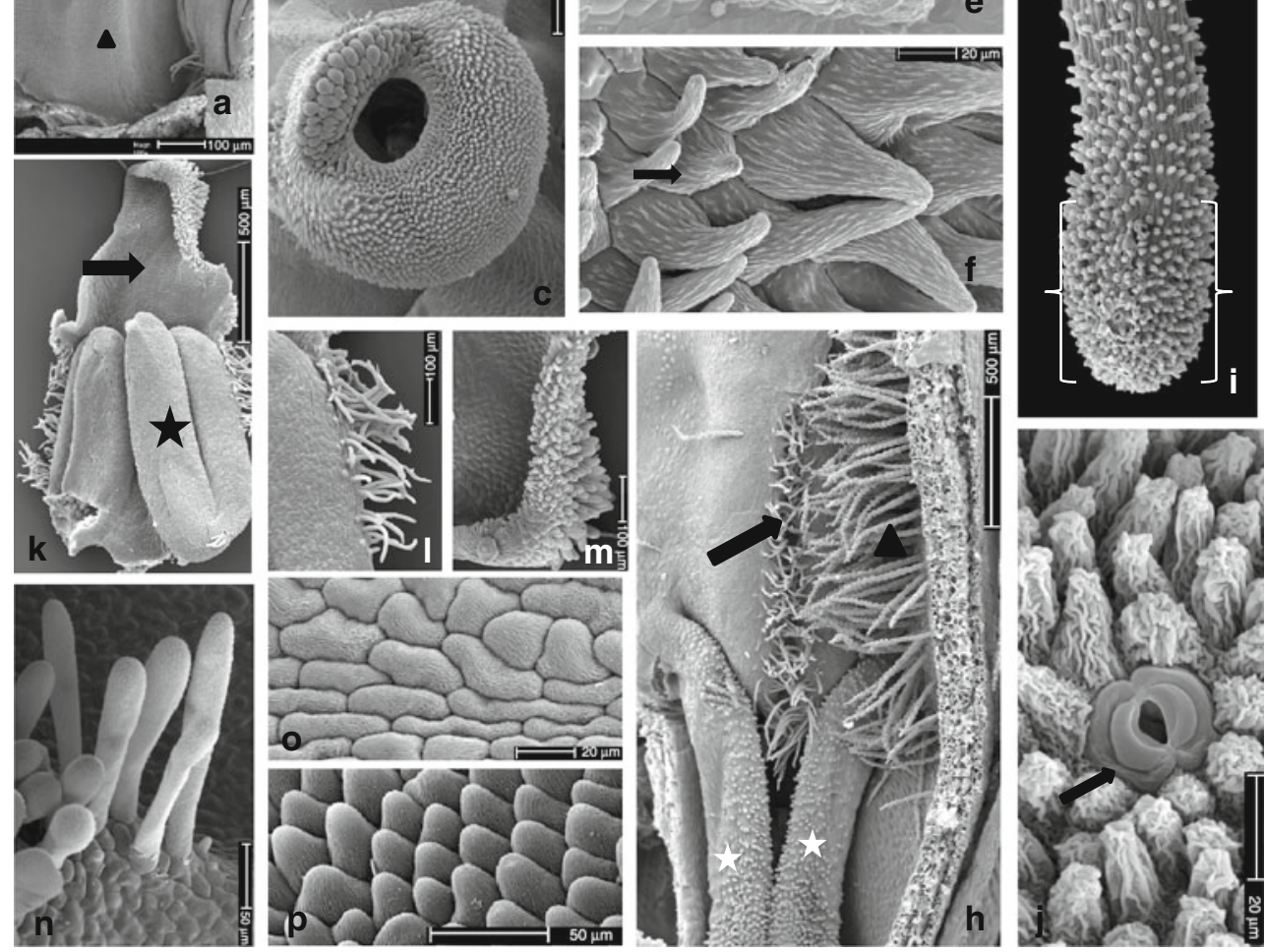

Fig. 7 Viola lutea ssp. westfalica from Blankenrode-flower parts (SEM): a pistil with style, stigma and ovary (arrowhead); visible anther (star) and stamen appendix (asterisk). b-f Stigma with hollow, papillae (asterisk, magnified in e) and hairs (arrow, magnified in f). g Stigma covered by exudate. $\mathbf{h}$ Part of anterior petal with hairs (arrowhead), stamen with hairs (arrow) and two nectaries (asterisks) connected with stamens. i, j Nectary with papillae in basal part

(arrow) and hairs in apical part (parentheses), stomata in epidermis (arrow, magnified in $\mathbf{j}$ ). $\mathbf{k}-\mathbf{m}$ Filamentless stamens with anthers (asterisk) and appendix (arrow), visible stamen hairs (magnified in l) and appendix hairs (magnified in $\mathbf{m}$ ). $\mathbf{n}-\mathbf{p}$ Lateral petal: hairs in basal part (n), abaxial epidermis cells (o) and adaxial epidermis cells (p)

\section{Discussion}

This is the most comprehensive study yet published on the macro- and micro-morphology of the reproductive organs in zinc violets, $V$. lutea and $V$. tricolor. Violets of sect. Melanium are specified by the following criteria, which differentiate them from others, for example, from members of sect. Viola: differences in flower color, corolla size and shape, lateral petal position, stigma morphology, length of

the nectar spur and nectariferous appendages of the stamens (Kraemer 1899; Church 1908; Clausen 1929; Valentine 1962; Valentine et al. 1968; Bernardello 2007), and pollination ecology (Church 1908; Beattie 1971, 1972, 1974). Because the morphological characters of pansy flowers vary within species and are influenced by developmental, genetic or environmental factors (Kristofferson 1923), here we used additional micro-morphological characters for diagnosis of the violets. 
Fig. 8 Pollen morphology and heteromorphism: a-e Viola lutea from the Vosges

Mountains: a visible 4- and 5-aperturate pollen grains. b 3-aperturate pollen grain with tenuitas at pole (asterisk). c 4-aperturate pollen grain with tenuitas at pole (asterisk). d 4-aperturate pollen grain with porus at pole (asterisk). e 5-Aperturate pollen grain. $\mathbf{f}-\mathbf{j}$ V. tricolor pollen grain morphology (f), 3-aperturate pollen grain $(\mathbf{g})$, 4-aperturate pollen grains $(\mathbf{h}, \mathbf{i}), 5$-aperturate pollen grain $(\mathbf{j})$
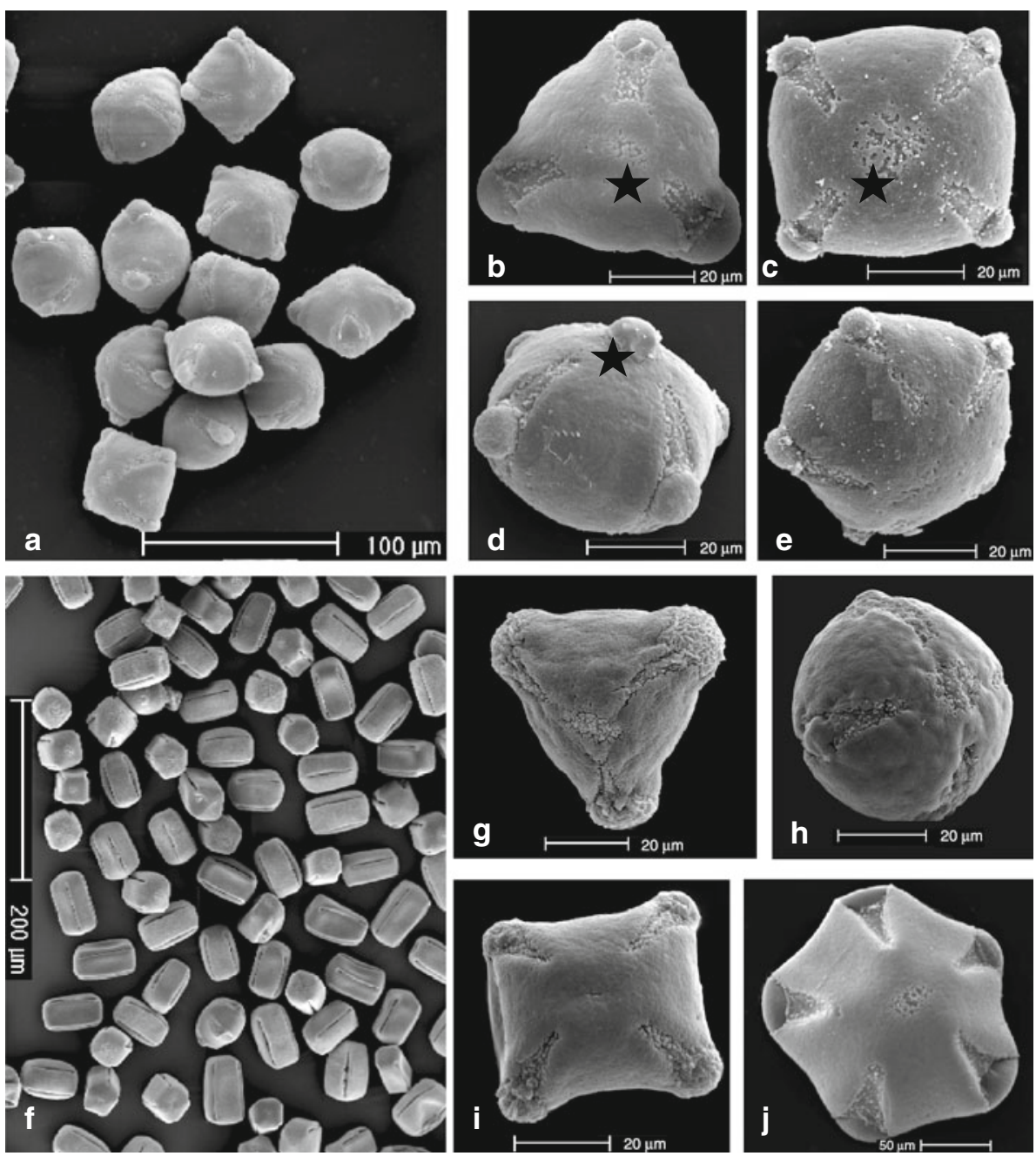

The study revealed great similarity between the species, but whenever differences were noted there was a match between the two zinc violets and $V$. lutea, but not with $V$. tricolor. The most evident features were (a) the pattern of dark stripes (nectar guides) on lateral and spurred petals, which are branched in both zinc violets and in V. lutea, but not branched in Viola tricolor (also in cultivated ornamental dwarf form of Viola x wittrockiana; authors' observations); (b) the position of the posterior petals; and (c) the shape, abundance and distribution of papillae and hairs on nectariferous stamina appendages (nectaries).

It has been argued that the leaf morphology of the blue zinc violet and V. tricolor is similar (Nauenburg 1986). Leaf morphology is known to be a mutable character influenced by environmental conditions (Stuessy 2009). Our observations also suggest that leaf morphology is not a dependable character for diagnosis of violets of sect. Melanium (Słomka et al. 2011c). The argument about chromosome numbers is more difficult to dismiss. As discussed in detail by Hildebrandt et al. (2006), if the blue zinc violet arose by autopolyploidization from $V$. tricolor, it would have resulted in a highly unstable species with irregular meiosis and reduced pollen viability. It is more likely that both zinc violets evolved from $V$. lutea by hybridization or mutations (structural chromosome or gene mutations) (Siuta et al. 2005). Here we note that the chromosome numbers in $V$. lutea have now been determined as $2 n=48,50$ and also 52 (Marhold et al. 2007; http://www.floranordica.org), and have not been finally resolved for $V$. lutea ssp. calaminaria (see Introduction). Uncertainty about the determinations means that chromosome numbers do not provide a firm basis for arguing the relatedness of the blue zinc violet to $V$. tricolor.

This study yielded the most detailed information yet on generative organ micromorphology in the examined violet taxa, from which the pollination mechanisms can be inferred. Flower structure is designed to mechanically prevent self-pollination and to adapt to pollination by insects for which several characters are attractants, such as petal color, lines on lateral and anterior petals, or the green spot on the style that guides pollinators to the source of nectar deposited in the spur, as evident from all the figures 
Fig. 9 Pollen morphology and heteromorphism: a-d Viola lutea ssp. calaminaria:

a 3-aperturate pollen grains, magnified (b-d) with visible tenuitas at pole (asterisk), note dwarf pollen grain (arrow on b) e-j V. lutea ssp. westfalica: e, $\mathbf{f}$ 4-aperturate normal pollen and degenerated, dwarf pollen grains (arrows on $\mathbf{e}, \mathbf{f}$ ),

3 -aperturate pollen grain (g), 4-aperturate pollen grains with tenuitas at pole (asterisks) $(\mathbf{h}-\mathbf{j})$
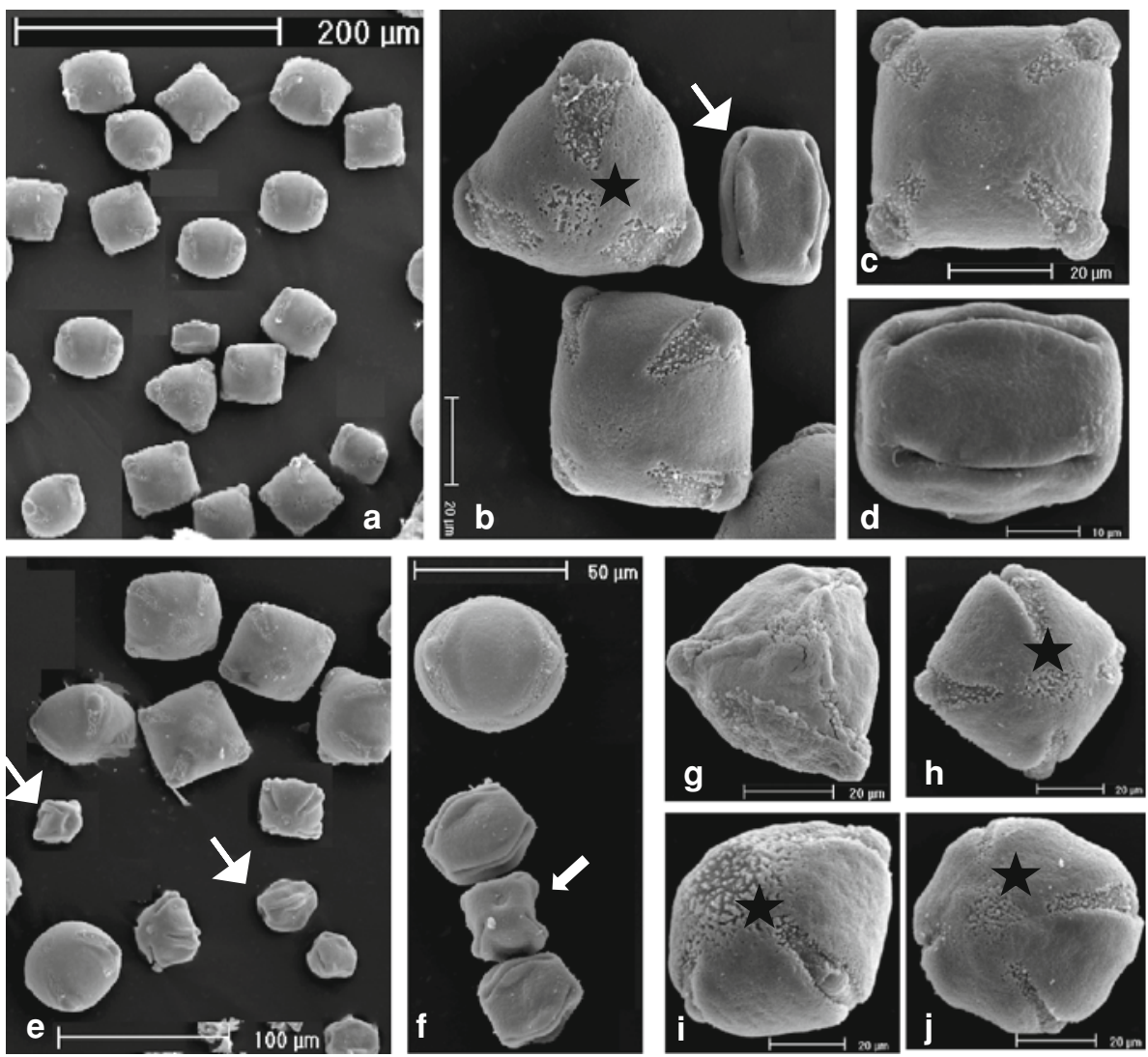

we present. The nectar is produced by epidermal cells of anther appendages, which is then transferred and stored in the spur for secondary presentation (Vogel 1998; Fahn 1979; Freitas and Sazima 2003; Pacini et al. 2003). An additional attractant for pollinators is the petal adaxial epidermis with its conical papillae covered by a striated cuticle forming a velvety surface.

Female and male organ positions prevent self-pollination. Five filamentless stamens very closely surround the ovary. Yellowish to orange apical anther appendages form a cone around the style just below the stigma, in which pollen is shed and kept. Cross-pollination occurs because pollen is available for long-tongued and medium-tongued nectar-seeking insects, such as honeybees, bumblebees, solitary bees and bee flies (Beattie 1971).

In regard to their ancestry, the zinc violets seem to be glacial relicts. They may have survived only on heavy metal heaps due to poor competitiveness. The emergence of the two different zinc violets, which are at best subspecies of Viola lutea, may be due to isolation. Separation may have occurred even rather recently, during medieval times. Then miners may have transported seeds from place to place with their tools (Kakes and Everards 1976). Alternatively, sheep grazing, carried on from the Sudeten Mountains to even the French Auvergne in medieval times, may have transported seeds in sheep wool (Ellenberg 1988). Due to its recent development, the blue zinc violet with its disturbed meiosis has not stabilized yet (Siuta et al. 2005). Restriction to heavy metal sites may have occurred by adaptation due to gene mutations or duplications, as recently shown in a comparison of $V$. tricolor samples from waste heaps with those from unpolluted sites (Słomka et al. 2011a). Adaptation of metallophyte plants to heavy metal soils is seen to have arisen by gene multiplications (Verbruggen and Schat 2009; Krämer 2010). Arbuscular mycorrhizal fungi may have helped them to survive. They are strongly mycorrhizal, unlike alpine $V$. lutea (Słomka et al. 2011b).

All the evidence indicates that blue and yellow zinc violets are subspecies or even only varieties of $V$. lutea. We see no support for separating the blue zinc violet of Blankenrode as the species $V$. guestphalica, and it shows no relatedness to $V$. tricolor.

Acknowledgments We thank Dr. Ralf Buchner (University of Vienna) for very helpful discussions on pollen nomenclature.

Open Access This article is distributed under the terms of the Creative Commons Attribution Noncommercial License which permits any noncommercial use, distribution, and reproduction in any medium, provided the original author(s) and source are credited. 


\section{References}

Beattie AJ (1971) Pollination mechanisms in Viola. New Phytol 70:343-360

Beattie AJ (1972) The pollination ecology of Viola. Pollen loads of insect-visitors. Watsonia 9:13-25

Beattie AJ (1974) Floral evolution in Viola. Ann Missouri Bot Gard 61(3):781-793

Bernardello $G$ (2007) A systematic survey of floral nectaries. In: Nicolson SW, Nepi M, Pacini E (eds) Nectaries and nectar. Springer, New York, pp 19-128

Bizoux J-P, Brevers F, Meerts P, Graitson E, Mahy G (2004) Ecology and conservation of Belgian populations of Viola calaminaria, a metallophyte with a restricted geographic distribution. Belg $\mathrm{J}$ Bot 137:91-104

Bizoux J-P, Dad̆nou K, Raspé O, Lutts S, Mahy G (2008) Fitness and genetic variation of Viola calaminaria, an endemic metallophyte: implications of population structure and history. Plant Biol 10:684-693

Church AH (1908) Types of floral mechanism, part 1. Clarendon Press, Oxford

Clausen J (1927) Chromosome number and the relationship of species in the genus Viola. Ann Bot 41:678-714

Clausen J (1929) Chromosome number and the relationship of some North American species of Viola. Ann Bot 43:741-764

Dajoz I (1999) The distribution of pollen heteromorphism in Viola: possible role of ploidy variations and pollination ecology. Evol Ecol Res 1:97-109

Ellenberg H (1988) Vegetation ecology of Central Europe. Cambridge University Press, Cambridge

Ernst WHO (1974) Schwermetall vegetation der Erde. Gustav Fischer, Stuttgart

Fahn A (1979) Secretory tissues in plants. Academic Press, New York

Freitas L, Sazima M (2003) Floral biology and pollination mechanisms in two Viola species-from nectar to pollen flowers? Ann Bot 91:311-317

Gadella TWJ (1963) A cytotaxonomic study of Viola in the Netherlands. Acta Bot Neerl 12:17-39

Halbritter H (1998) Preparing living pollen material for scanning electron microscopy using 2, 2-dimethoxypropane (DMP) and critical-point drying. Biotech Histochem 73:137-143

Hildebrandt U, Hoef-Emden K, Backhausen S, Bothe H, Bożek M, Siuta A, Kuta E (2006) The rare, endemic zinc violets of Central Europe originate from Viola lutea Huds. Plant Syst Evol 257:205-222

Kakes P, Everards K (1976) Genecological investigations on zinc plants I. Genetics of flower colour in crosses between Viola calaminaria Lej. and its subspecies westfalica (Lej.) Ernst. Acta Bot Neerl 25:31-40

Kraemer H (1899) The morphology of the genus Viola. Bull Torrey Bot Club 26(4):172-183

Krämer U (2010) Metal hyper-accumulation in plants. Annu Rev Plant Biol 61:517-534

Kristofferson KB (1923) Crossing in Melanium violets. Hereditas 4:251-289

Kroon GH (1972) Some aspects of the pollination mechanism of Viola tricolor L. and Viola $\times$ wittrockiana Gams. Acta Bot Neerl 21(6):630-632
Lucassen E, Van Kempen MML, Roelofs JGM, Van der Velde G (2010) Decline in metallophytes in tertiary polluted floodplain grassland in the Netherlands, experimental evidence for metal and nutritional changes in soil as driver factors. Chem Ecol 26:273-287

Marhold K, Mártonfi P, Mered'a P Jr, Mráz P (2007) Chromosome number survey of the ferns and flowering plants of Slovakia. Veda, Bratislava, pp 433-435

Nadot S, Ballard HE, Creach JB, Dajoz I (2000) The evolution of pollen heteromorphism in Viola: a phylogenetic approach. Plant Syst Evol 223:155-171

Nauenburg J (1986) Untersuchungen zur Variabilität, Ökologie und Systematik der Viola tricolor- Gruppe in Mitteleuropa. Dissertation zur Erlangung des Doktorgrades. Universität zu Göttingen

Pacini E, Nepi M, Vesprini JL (2003) Nectar biodiversity: a short review. Plant Syst Evol 238:7-21

Schmeil O, Fitschen J (2010) Die flora Deutschlands und der angrenzenden Länder, 95th edn. Quelle und Meyer, Wiebelsheim

Siuta A, Bożek M, Jędrzejczyk M, Rostański A, Kuta E (2005) Is the blue zinc violet (Viola guestphalica Nauenb.) a taxon of hybrid origin? Evidence from embryology. Acta Biol Cracov ser Bot 47:237-245

Słomka A, Kawalec P, Kellner K, Jędrzejczyk-Korycińska M, Rostański A, Kuta E (2010) Was reduced pollen viability in Viola tricolor $\mathrm{L}$. the result of heavy metal pollution or rather the test applied? Acta Biol Cracov ser Bot 52(1):123-127

Słomka A, Sutkowska A, Szczepaniak MP, Malec P, Mitka J, Kuta E (2011a) Increased genetic diversity of Viola tricolor L. (Violaceae) in metal-polluted environments. Chemosphere 83:435-442

Słomka A, Kuta E, Szarek-Łukaszewska G, Godzik B, Kapusta P, Tylko G, Bothe H (2011b) Violets of the section Melanium, their colonization by arbuscular mycorrhizal fungi and their occurrence on heavy metal heaps. J Plant Physiol 168(11):1191-1199

Słomka A, Jędrzejczyk-Korycińska M, Rostański A, Karcz J, Kawalec P, and Kuta E (2011c) Heavy metals in soil affect reproductive processes more than morphological characters in Viola tricolor. Environ Exp Bot. doi:10.1016/j.envexpbot.2011. 07.003

Słomka A, Siwińska D, Wolny E, Kellner E, Kuta E (2011d) Influence of a heavy-metal-polluted environment on Viola tricolor genome size and chromosome number. Acta Biol Cracov ser Bot 53(1): $7-15$

Stuessy TF (2009) Plant taxonomy. The systematic evaluation of comparative data. Columbia University Press, New York

Valentine DH (1962) Variation and evolution in the genus Viola. Preslia 34:190-206

Valentine DH, Merxmüller H, Schmidt A (1968) Viola L. In: Tutin TG, Heywood VH, Burges NA, Moore DM, Valentine DH, Walters SM, Webb DA (eds) Flora Europaea, vol. 2. University Press, Cambridge, pp 270-282

Verbruggen NC, Schat H (2009) Molecular mechanisms of metal hyper-accumulation in plants. New Phytol 181:759-776

Vogel S (1998) Remarkable nectaries: structure, ecology, organophyletic perspectives IV. Miscellaneous cases. Flora 193:225-248 